\title{
Digestive Enzymes in Marine Species. II. Amylase Activities in Gut from Seabream (Sparus aurata), Turbot (Scophthalmus maximus) and Redfish (Sebastes mentella)
}

\author{
R. Munilla-Moran and F. Saborido-Rey \\ INSTITUTO DE INVESTIGACIONES MARINAS C.S.I.C., EDUARDO CABELLO, \\ 6. E-36208 VIGO (PONTEVEDRA), SPAIN
}

Correspondence to: R. Munilla-Moran, Instituto de Investigaciones Marinas, C.S.I.C., Eduardo Cabello, 6. E-36208 Vigo (Pontevedra), Spain. Tel. + 34-86-23-19-30; Fax + 34-86-29-27-62.

Abbreviations- PCMB, p-hydroxymercuribenzoate; IAA, iodoacetamide.

\begin{abstract}
The amylase activity of the digestive tract of three carnivorous fish species (Sparus aurata, Scophtalmus maximus and Sebastes mentella) has been studied. The activity of seabream and turbot showed its maximum at neutral $\mathrm{pH}(7.0-7.5)$; meanwhile, the activity of redfish had an optimum $\mathrm{pH}$ at 4.5-5.0. The $\mathrm{t}^{\mathrm{o}}$ function ranged between 35 and $45^{\circ} \mathrm{C}$ for the three species. The Arrhenius plots of the intestinal activities of seabream and turbot showed breakpoints at temperatures close to those of their physiological activities. High saline concentrations inhibited the activity of seabream and turbot and activated the activity of redfish. Seabream activity was absolutely dependent on calcium ions. On the contrary, redfish activity was only detected in the absence of this metal. Studies carried out by using several effecters suggested that the activities found in these three species are different. Considering our results from a point of view of the environmental conditions of these species, it might be concluded that enzymatic digestion of dietary carbohydrates proceeds at very low rate. Physiological implications are discussed.
\end{abstract}

KEY WORDS. Carbohydrate digestion, amylases, carnivorous marine fish, stomach, intestine, Sparus aurata, Scophthalmus maximus, Sebastes mentella 
Because of the fact that fish do not mobilize liver glycogen during starvation and no nutritional requirements have been described for carbohydrates, these do not seem to be nutritionally important for fish (1). Contrary to what happens in other high vertebrates, fishes fulfill their fuel requirements from protein, fat and sugar. Nevertheless, enzymatic digestion of carbohydrates (starch) has been detected in the gut of all species so far studied. Enzymatic hydrolysis of starch is started by the action of amylase activity. There are two major types of this enzyme: $\alpha$ and $\beta$. Type $\beta$ is found in vegetals and type $\alpha$ is found in animals (2).

Amylase levels are affected by the filling degree of the gut $(3,4)$ and the nutritional condition of the animal. Higher levels are detected when the fish is not starved $(2,5)$. Also, herbivorous and omnivorous species have been reported to have more amylase activity than carnivorous species $(2,6,7)$. Higher enzymatic levels have also been reported for younger than adults in the same species $(5,8)$.

As in mammals, amylase is produced in the pancreas and, when required, secreted into the gut $(2,6,9)$ where the enzyme is mainly adsorbed onto the mucosa of the intestine and the pyloric ceca (if present) $(5,8,10)$. Some authors have not found amylase activity in stomach homogenates $(7,11,12)$ and proposed that gastric amylase activity might be due to exogenous contamination whether from the intestinal contents (by regurgitation) or from the ingested food.

The importance of gaining knowledge about amylase activity in fish species has been indicated by Buddington and Doroshow (13). These authors concluded that the low amylase levels in white sturgeon are responsible for the scarce potential of this species to exploit diets with high carbohydrate contents. Despite this, there is a lack of information about the characterization of amylase activity in fishes. No attempt has been made to know what type of amylase is present in different species. On the other hand, comparison of information about enzymes in fishes (amylase is not an exception) is hampered by the use of heterogeneous substrates and methods of measurement $(3,12)$.

This article, which forms part of a series devoted to enzymatic digestion in fishes and overcoming that problem, deals with the characterization of amylase activity in three carnivorous marine fish species: redfish (Sebastes mentella), seabream (Sparus aurata) 
and turbot (Scophthalmus maximus). In this work, activities detected in stomach and intestine have been studied separately.

\section{MATERIALS AND METHODS}

\section{Experimental Fish}

Redfish (S. mentella) adults were obtained during the EU (European Union) stratified bottom trawl survey on Flemish Cap Bank (NAFO Northwest Atlantic Fisheries Organization Div. 3M) at East of Newfoundland. Fish were sampled in summer from the same area, the East of Flemish Cap (Strata 14 and 15), at depths ranging between 420 and $480 \mathrm{~m}$. Only fishes caught in summer were used in this study to avoid changes specimens, identified as S. mentella with the passage of the extrinsic gassbladder musculature between different ventral ribs $(15,16)$, were frozen onboard at $-30^{\circ} \mathrm{C}$ for further studies in the laboratory.

Turbot (S. maximus) and seabream (S. aurata) adults were purchased from a 'commercial fish farm of the Northwest of Spain (Cultivos de Peces, S. A., O Grove, Pontevedra). The fishes were kept in running seawater $\left(\approx 15-18^{\circ} \mathrm{C}\right)$ and fed ad libitum on semimoist diets. The specimens used for this study were obtained in October

Fish were harvested by the fish farm staff, killed by a blow to the head and kept in the freezer until dissection of the gastrointestinal tract (usually done within $3 \mathrm{hr}$ and never at temperatures above $\mathrm{O}^{\circ} \mathrm{C}$ ).

Data concerning number, size, weight of fish and food compositions are given in Table 1. The sizes of the tanks where turbot and seabream were ongrown are also provided.

\section{Preparation of Homogenates}

All procedures were conducted in the cold $\left(0-4^{\circ} \mathrm{C}\right)$, unless otherwise stated. Fishes were individually measured and weighed, and the whole gut was dissected. Guts were longitudinally cut open and contents removed by scraping with a plastic slide. Then, after discarding the pyloric ceca, the stomachs and the intestines were sliced into small 
pieces, washed in distilled water, centrifuged at $2000 \mathrm{rpm}$ for $5 \mathrm{~min}$ and frozen at $-18^{\circ} \mathrm{C}$ until use. Stomachs of the same species were put together before freezing, and the same was done for the intestines.

Tissues were thawed by stirring them with Tris- $\mathrm{HCl} 0.02 \mathrm{M}$ buffer, $\mathrm{pH} 8.2$ (1:4, wet weight: volume) for half an hour at room temperature. The suspensions were homogenized using an Ultraturrax at 25,000 rpm for 2 x 1-min pulses, and the extracts were cleared by centrifuging at 14,000 rpm for $60 \mathrm{~min}$, dialyzed overnight against -150 volumes of buffer and then re-centrifuged at 14,000 rpm and the supernatants used immediately or stored deep frozen $\left(-77^{\circ} \mathrm{C}\right)$ in small aliquots $(0.2 \mathrm{ml})$ until needed. These fractions were used for amylolytic activity and protein content measurements.

Enzyme Activity

Total amylase activity was measured using soluble starch as substrate as described in Munilla-Moran and Stark (17). A typical assay was performed as follows: $0.125 \mathrm{ml}$ of appropriate buffer, $0.125 \mathrm{ml}$ of soluble starch ( $2 \%$ in distilled water) and $0.05 \mathrm{ml}$ of enzymatic extract were mixed and incubated for $1 \mathrm{hr}$ under the specific conditions of the experiment ( $\mathrm{pH}$, temperature and so on). The reaction was stopped by adding $0.25 \mathrm{ml}$ of the first reagent of Somogy-Nelson (18). Controls were made in the same way, but the enzymatic extracts were added at the end of the incubation period. Reducing sugars were determined using the Somogy-Nelson method (18), using maltose as standard. One unit of activity was defined as the amount of enzyme that liberates $1 \mu \mathrm{g}$ of maltose $/ \mathrm{hr}$. Enzymatic extracts were diluted if required. Results are the mean of three independent experiments.

The effect of $\mathrm{pH}$ on the hydrolysis of starch was tested with the following $0.1 \mathrm{M}$ buffers: glycine- $\mathrm{HCl}$ ( $\mathrm{pH} 1.0-2.5)$, phosphate-citrate ( $\mathrm{pH}$ 2.5-8.0), Tris- $\mathrm{HCl}$ (8.0-10.5) and glycine- $\mathrm{NaOH}(\mathrm{pH} 10.5-12.0)$. The effect of temperature was measured at the optimal $\mathrm{pH}$ found for the respective segment. The study of $\mathrm{NaCl}$ concentration on the total amylase activity was carried out by using the buffers with adequate concentrations of the salt. Effecters were left to react with the enzymes for $30 \mathrm{~min}$ at room temperature before adding the enzymatic extract to the reaction mixture. When studying the effect of these compounds, the optical readings were corrected according the absorbance at 600 
$\mathrm{nm}$ due to the compound. Soluble protein content of the homogenates were determined by the method of Miller (19), using bovine serum albumin as standard.

All chemicals used in this study were reagent grade and obtained from Sigma (St. Louis, MO, USA) unless otherwise stated.

\section{RESULTS}

\section{Effect of $\mathrm{pH}$}

To determine optimum $\mathrm{pH}$ values for the amylase activity, a $\mathrm{pH}$ range between 2 and 12 was investigated by using the following $0.1 \mathrm{M}$ buffers: glycine- $\mathrm{HCl}(\mathrm{pH} 2-2.5)$, phosphatecitrate $(\mathrm{pH} 2.5-8)$, Tris- $\mathrm{HCl}(\mathrm{pH}$ 8-10.5) and glycine- $\mathrm{NaOH}(\mathrm{pH} 10-12)$. The results are shown in Fig. 1, A and B. In redfish, the maximum activity was found in the acid range ( $\mathrm{pH} 4.5-5)$ for both sites, the stomach and intestine. However, other peaks of activity appeared in the slightly alkaline zone. This second peak was higher in the stomach than in the intestine. Turbot also showed to have an amylase activity with two peaks, although the most pronounced peak was found at $\mathrm{pH}$ 7. Similarly to the findings in redfish, this secondary peak of activity was more pronounced in the stomach ( $\mathrm{pH} 5.5)$ compared with the intestine ( $\mathrm{pH} 4.5)$. Seabream only showed one $\mathrm{pH}$ optimum both in stomach and intestine ( $\mathrm{pH}$ 7-7.5). In no case was starch hydrolysis at $\mathrm{pH}$ values below 5 measured in this species.

\section{Effect of Temperature}

The highest starch hydrolysis activity was recorded at 35,40 and $45^{\circ} \mathrm{C}$ in stomach from redfish, seabream and turbot, respectively (Fig. 2A). Very low activities were measured at low temperatures $\left(-5^{\circ} \mathrm{C}\right)$. Intestinal extracts (Fig. 2B) of redfish had the highest activity at $40^{\circ} \mathrm{C}$ and turbot showed a maximum of activity at $45^{\circ} \mathrm{C}$. Seabream intestinal optimum activity was found between these two temperatures. Redfish retained more activity at low temperatures than seabream and turbot. In all cases, a sharp decrease of the activity was observed above optimal temperature. 
Data were linearized by using Arrhenius plot. However, the results of the intestinal activities of seabream and turbot could not be linearized by one single straight line. The point at which both lines cross is named "breakpoint" (10). The extrapolation of this breakpoint on the abscissa axis gives us the "breakpoint temperature." Breakpoint temperatures, energy of activation $(\mathrm{Ea})$ and $\mathrm{Q}_{10}$ values are summarized in Table 2 . The breaks on the Arrhenius plots were at 19.9 and $23.6^{\circ} \mathrm{C}$ for seabream and turbot, respectively. Ea values ranged between 2.40 and $19.13 \mathrm{kcal} / \mathrm{mol}$. In seabream and turbot intestine, higher Ea values were calculated for temperatures below the breakpoint.

\section{Effect of Salt Concentration}

The three species used in this work are marine organisms. In consequence, salt concentration in the digestive tract increases with ingestion of food. To test the effect of salt concentration on the ability to digest starch, the assays were carried out under different $\mathrm{NaCl}$ concentrations ranging from 0 (considered as controls) to $0.5 \mathrm{M}$. The results obtained for stomach activity are shown in Fig. 3A and those for intestine in Fig. 3B.

In redfish, the amylase activity was enhanced by $\mathrm{NaCl}$ (throughout all the range tested). This effect was higher in stomach than intestine. In turbot, low $\mathrm{NaCl}$ concentrations increased the amylase activity but high salt concentrations inhibited. In seabream, the activity was strongly depressed by salt. However, a small increase was detected with low $\mathrm{NaCl}$ levels in the stomach.

\section{Effectors}

To identify the kind of amylase present in each species, the effect of several compounds on amylase activity was measured in the presence and absence of $10 \mathrm{mM}$ calcium chloride (final concentration). The results are shown in Table 3.

In seabream, no activity could be detected when calcium ions were removed from the assay mixture. Magnesium ions were not able to replace calcium, although a $1 \mathrm{kw}$ activity could be measured with copper. A great deal of the activity remained even after 
incubation with urea or p-hydroxymer-curibenzoate (PCMB). Iodoacetamide fully inhibited the activity.

Turbot enzyme(s) can act without calcium but at lower rates. Gastric activity was most affected by lack of calcium ions. Only a small difference in sensitivity towards PCMB was detected between assays with or without calcium. On the other hand, calcium had a stronger influence on the intestinal activity. When present, the activity was more resistant toward urea and iodoacetamide (IAA).

Redfish activity was measured at $\mathrm{pH} 4.8$. In this species, the opposite situation to that of seabream was found, resulting in maximal activity when calcium was removed from the assay mixture. Only in stomach extracts was some significant activity determined with urea present (Table 3).

\section{DISCUSSION}

Extracts prepared from tissues of stomachs and intestines of three carnivorous marine fish species (redfish, seabream and turbot) showed to have the ability to digest starch. This activity was present throughout the gut (including the pyloric ceca; data not shown). Therefore, the ability to hydrolyze carbohydrates (regardless of their feeding habits) in these species is established.

Cavital $\mathrm{pH}$ affects enzymatic activity. Intestinal $\mathrm{pH}$ values recorded in fish are in the neutral alkaline range $(2,9)$. On the other hand, $\mathrm{HCl}$ secretion into the stomach lumen seems to be restricted only for those species having a functional stomach $(2,20)$. The amount of secreted acid depends on the nutritional condition of the animal. In this work, no fasting conditions were applied, and, in most cases, bolus had to be discarded before preparing the extracts. This suggests that an acid $\mathrm{pH}$ should operate in the gastric chamber. On the contrary, alkaline conditions would prevail in the intestine. The $\mathrm{pH}$ value differently affected the amylase activity of the three species (Fig. 1). Some differences could even be detected between segments within the same species. This suggests that carbohydrate digestion in fishes might be more sophisticated than previously expected. 
According to $\mathrm{pH}$ dependence, the activity of seabream and turbot seems to be more similar to that reported for other fishes. Optimal $\mathrm{pH}$ values between 7.0 and 8.5 have been extensively reported $(2,3,6,9,12,13,22-28)$. However, it should be mentioned that the clear peak in the acid range in turbot stomach would mean that this species is able to start carbohydrate digestion sooner than seabream. On the contrary, redfish had the maximal activity in the acid range both in the stomach and in the intestine. This indicates that carbohydrate digestion starts in the stomach in this species. In short it seems that in seabream, sugar hydrolysis exclusively takes place in the intestine; this is mainly done in the stomach for redfish. In turbot, it might be started in the stomach and finished in the intestine.

Amylase activity was strongly dependent on temperature. A general pattern was found for the activities of the three species regarding the optimal temperature (to function). The optimal temperatures of $\alpha$-amylase activity reported for other fish species range from 25 to $55^{\circ} \mathrm{C}(12,23,29,30)$. Nevertheless, it should be borne in mind that these values are not physiological at all. Most of the fish species cited above would not survive at such a high temperatures. Also, protein (and hence enzyme) degradation starts at $\sim 40^{\circ} \mathrm{C}$.

However, more information can be gained by studying the $\mathrm{t}^{\mathrm{o}}$ function of this activity in these species. The intestinal $\alpha$-amylase activities of seabream and turbot showed a breakpoint in their Arrhenius plots. A biphasic plot has also been found for a-amylase and other digestive enzymes in fish guts $(10,29,31,32)$ and other marine organisms (33). According to Ugolev's group hypothesis, the more efficient activities (lower Ea values) (Table 2) in these species' intestines are in the temperature range of their physiological activity. On the other hand, small increments in temperature would produce a little enhancement of activity. Bearing in mind that the activity in this temperature range is reduced (below $25 \%$ of the maximal), it might be concluded that the ability to hydrolyze starch is reduced in these two species. The $\alpha$-amylase activity detected in the stomach of turbot and seabream can be neglected because it is unlikely to proceed under a strongly acid environment (Fig. 1).

At physiological (low) temperatures (34), higher activities were detected in redfish intestinal homogenates (Fig. 2). Nevertheless, as this activity has an acid pH optimum, 
it should hydrolyze starch at very low rates in the intestine, resulting again in a very limited capability to digest carbohydrates in this species. Although dairy vertical migrations for taking food has been described for redfish (35), no effect on starch digestion should be expected because water temperature variations are very limited in these migrations.

Despite this, the conclusion that these marine species are unable to use efficiently dietary carbohydrates should not be withdrawn. At low temperatures (under physiological conditions), the food is evacuated from the gut very slowly $(2,20,26,36-$ 40 ), thus increasing the time during which amylase is digesting carbohydrates.

There are several classes of amylase $(2,41-44)$. Animal $\alpha$-amylases are chloride ions dependent (being activated at low $\mathrm{NaCl}$ concentrations and inhibited at high concentrations), whereas vegetal $\beta$-amylases are not. Bacterial $\alpha$-amylases and lysosomal y-amylases have an acid optimum $\mathrm{pH}$ and are chloride independent. It should again be borne in mind that as the species studied in this work are marine species, food digestion must proceed under high saline (chloride) concentrations.

According to the response of the activities studied here toward increasing salt concentrations, it might be concluded that $\alpha$-endoamylases are present in the gut of seabream and turbot but not in redfish, where both activities were increased all along the $\mathrm{NaCl}$ concentration range tested. An activatory effect of low $\mathrm{NaCl}$ concentrations for intestinal amylases of other fish species has been previously reported $(9,23,26)$.

Inhibitors are very useful to discern among different types of amylases (45). On the other hand, as calcium has been described as essential for a-amylases stability $(24,42-$ 44), the effect of several inhibitors has been studied in the presence and absence of this metal.

The fact that no amylase activity could be detected in seabream homogenates when calcium was removed strongly suggests that an $\alpha$-type enzyme is present in this species. Because the activities of both stomach and intestine had similar responses against several effecters, this suggests that the same $\alpha$-amylase activity is present in both 
segments. The main difference between seabream amylase and that reported in other vertebrates is that in fish amylase calcium cannot be replaced with magnesium.

Similarly, turbot activity was maximal with calcium ions and is also likely to be of the $\alpha$-amylase class. However, the amylase activities from stomach and intestine showed differences, indicating that they are different proteins. The intestinal one appeared to be more dependent on calcium ions than the one of the stomach. In fact, the absence of this metal leads the intestinal enzyme to be more sensitive toward the effecters tested.

On the contrary, redfish amylase activity is likely to be of the $\beta$-type as the maximal activity was detected if calcium was removed from the assay mixture. This $\beta$-amylase seems to be the same both in stomach and intestine.

The characteristics of the activities found in these three carnivorous marine fish species suggest that enzymatic digestion of dietary carbohydrates is not very important. These enzymes do not seem to be very well suited to work under the environmental conditions expected in the fish gut (high saline concentrations, close to $0.5 \mathrm{M}$; low temperatures, between 5 and $20^{\circ} \mathrm{C}$ and, in the stomach, acid $\mathrm{pH}$ values, below c.a. $\mathrm{pH} 4.0$ ).

Therefore, it might be concluded that carbohydrate digestion proceeds at low rates in these carnivorous fish species. A slow production of monosaccharides in the gut lumen would avoid their accumulation and hence product inhibition of the enzyme $(46,47)$ will be reduced. As a consequence, "an excess luminal osmotic action" due to uncontrolled production of monosaccharides would be obviated (47).

Monosaccharides also inhibit the amino acid transport in the intestine and vice versa $(48,49)$. In fact, assimilation rates of glucose are lower in carnivorous fishes than in herbivorous $(48,50)$, whereas assimilation of amino acids is higher in carnivorous species. A low carbohydrate digestion (as seems to be the case in these three species) would produce low free monosaccharide concentrations in the gut lumen, thus favoring protein/amino acid utilization by these carnivorous species.

We thank 1. L. Rodriguez, biologist of Cultivos de Peces, S. A. (O Grove, Pontevedra, Spain) for turbot and seabream supplies and C. Barreiro and E. Calvar for technical 
assistance. This work was supported b a grant from the Xunta de Galicia XUGA40201 B90.

References

1. Cowey, C.B.; Sargent, J.R. Nutrition. In: Hoar, W.S.; Randall, D.J.; Brett, J.R., eds. Fish physiology, Vol. VIII. New York: Academic Press; 1979: pp. 1-69.

2. Vonk, H.J.; Western, J.R.H. Comparative biochemistry and physiology of enzymatic digestion. London: Academic Press; 1984.

3. Bitterlich, G. Digestive enzyme pattern of two stomachless filter feeders, silver carp, Hypophthamichthys molitrix Val., and bighead carp, Aristichthys nobilis Rich. J. Fish Biol. 27: 103-112; 1985.

4. Takii, K.; Shimeno, S.; Takeda, M. Changes in digestive enzyme activities in eel after feeding. Bull. Jpn. Soc. Sci. Fish., 51: 2027-2031; 1985

5. Munilla-Moran, R.; Stark, J.R. Metabolism in marine flatfish. VI. Effect of nutritional state on digestion in turbot, Scophthalmus maximus (L.). Comp. Biochem. Physiol., 95B: 625-634; 1990.

6. Fish, G.R. The comparative activity of some digestive enzymes in the alimentary canal of Tilapia and Perch. Hydrobiologia, XV: 161-178; 1960.

7. Sabapathy, U.; Teo, L.H. A quantitative study of some digestive enzymes in the rabbitfish, Siganus canaliculatus, and the sea bass, Lates calcarifer. J. Fish Biol., 42: 595-602; 1993.

8. Kawai, S.; lkeda, S. Studies on digestive enzymes of fishes. I. Carbohydrases in digestive organs of several fishes. Bull. Jpn. Soc. Sci. Fish., 37: 333-337; 1971.

9. Barrington, E.J.W. The alimentary canal and digestion. In: Brown, M.E., ed. The physiology of fishes: Metabolism. Vol. I. New York: Academic Press; 1957: pp. 109-161.

10. Ugolev, A.M.; Egorova, V.V.; Kuzmina, V.V.; Grudskov, A.A. Comparativemolecular characterization of membrane digestion in fish and mammals. Comp. Biochem. Physiol., 76B: 627-635; 1983.

11. Anderson, T. A. Mechanisms of digestion in the marine herbivore, the ludderick, Girella tricuspidata (Quoy and Gaimard). J. Fish Biol., 39: 535-547; 1991.

12. Uys, W.; Hecht, T. Assays on the digestive enzymes of sharptooth catfish, Clarias gariepinus (Pisces: Claridae). Aquaculture, 63: 301-313; 1987. 
13. Buddington, R.K.; Doroshov, S.I. Digestive enzyme complement of white sturgeon (Acipenser transmontanus). Comp. Biothem. Physiol., 83A: 561-567; 1986.

14. Hofer, R. The adaptation of digestive enzymes to temperature, season and diet in roach, Rutilus rutilus, and rudd, Scardinius erythrophthalmus; Proteases. J. Fish Biol., 15: 373-379; 1979.

15. Ni, I.-H. Separation of sharp beaked redfish Sebastes fasciatus and S. mentella from Northeastern Grand Bank by morphology of extrinsic gassbladder musculature. J. North Atl. Sci., 2: 7-12; 1981.

16. Power, D.J.; Ni, I.-H. Morphology of the extrinsic gassbladder musculature in the Golden Redfish, Sebastes maims. J. North. Atl. Sci., 3: 165-168; 1982.

17. Munilla-Moran, R.; Stark, J.R. Protein digestion in early turbot larvae, Scophthalmus maximus (L.). Aquaculture, 81: 315-327; 1989.

18. Robyt, J.F.; Whelan, W.J. The $\beta$-amylases. In: Radley, J.A., ed. Starch and its derivatives. London: Academic Press; 1968: pp. 477-497.

19. Miller, G.L. Protein determination for large numbers of samples. Anal. Chem., 31: $964 ; 1959$

20. Fänge, R.; Grove, D. Digestion. In: Hoar, W.S.; Randall, D.J.; Brett, J.R., eds. Fish physiology, Vol. VIII. New York: Academic Press; 1979: pp. 161-260.

21. Maier, K.J.; Tullis, R.E. The effects of diet and digestive cycle on the gastrointestinal tract $\mathrm{pH}$ values in the goldfish, Carassius aurata L., Mozambique tilapia, Oreochromis mossambicus (Peters), and channel catfish, Ictalarus punctatus (Rafinesque). J. Fish Biol., 25: 151-165; 1984,

22. Overnell, J. Digestive enzymes of the pyloric caeca and of their associated mesentery in the cod (Gadus morhua). Comp. Biothem. Physiol., 46B: 519-531; 1973.

23. Chiu, Y.N.; Benitez, L.V. Studies on the carbohydrases in the digestive tract of the milkfish Chanos chanos. Mar. Biol., 61: 247-254; 1981.

24. Clark, J.; McNaughton, J.E.; Stark, J.R. Metabolism in marine flatfish. I. Carbohydrate digestion in Dover sole (Solea solea L.). Comp. Biochem. Physiol., 77B: 821-827; 1984.

25. Glass, H.J.; MacDonald, N.L.; Stark, J.R. Metabolism in marine flatfish. IV. Carbohydrate and protein digestion in Atlantic halibut (Hippoglossus hippoglossus L.). Comp. Biochem. Physiol., 101B: 205-208; 1987. 
26. Smith, L.S. Digestive functions in teleost fishes. In: Halver, J.E., ed. Fish Nutrition, 2nd ed. London: Academic Press; 1989: pp. 331-421.

27. Ugwumba, A.A.A. Carbohydrases in the digestive tract of the African bony-tongue Heterotis niloticus (Pisces: Osteoglicosidae). Hydrobiologia, 257: 95-100; 1993.

28. Wigglesworth, J.M.; Griffith, D.R.W. Carbohydrate digestion in Penaeus monodon. Mar. Biol., 120: 571-578; 1994.

29. Ugolev, A.M.; Kuzmina, V.V. Membrane hydrolases of fish enterocytes. Temperature adaptations. Comp. Biochem. Physiol., 106B: 433-452; 1993.

30. Sabapathy, U.; Teo, L.H. Some kinetic properties of amylase from the intestine of the rabbitfish, Siganus canaliculatus. Comp. Biochem. Physiol. 109B: 139-144; 1994.

31. Somero, G.N.; Hochachka, P.W. The effect of temperature on catalytic and regulatory functions of pyruvate kinase of the rainbow trout and the Antarctic fish Trematornus bernachii. Biochem. J., 110: 395-400; 1968.

32. Gelman, A.; Cogan, U.; Mokady, S. The thermal properties of fish enzymes as a possible indicator of the temperature adaptation potential of the fish. Comp. Biochem. Physiol., 101B: 205-208; 1992.

33. Oosthuizen, V.; Naude, R.J.; Oelofsen, W. The isolation and partial characterization of $\alpha$-amylase from the pancreas of the ostrich (Struthio camelus). Comp. Biochem. Physiol., 101B: 277-282; 1992.

34. Dolgov, A.V.; Drevetnyak, K.V. Estimation of rations and food consumption of deep-water redfish (Sebastes mentella) from the Norwegian-Barents Sea stock. I.C.E.S., C.M. 1990; G:11, 15 pages; 1990.

35. Konchina, Y.V. Main trophic relationships of redfishes in the Northwest Atlantic. NAFO SCR DCC. 83/1X/75. Serial No. N 741; 1983.

36. Flowerdew, M.W.; Grove, D.J. Some observations of the effects of body weight, temperature, meal size and quality on gastric emptying time in turbot, Scophthalmus maximus (L.) using radiography. J. Fish Biol., 14: 229-238.

37. lkehara, K.; Nagahara, M. Fundamental studies for establishing rockfish culture techniques. VI. The protein digesting ability and the favourable contents of protein in diets for the rockfish Sebastes schlegeli. Bull. Jpn. Sea Reg. Fish. Res. Lab., 31: $65-72 ; 1980$. 
38. Holmgren, S.; Grove, D.J.; Fletcher, D.J. Digestion and the control of gastrointestinal motility. In: Rankin, J.C.; Pitcher, T.J.; Duggan, R.T., eds. Fish Physiology: Recent advances. London: Croom Helm; 1983: pp. 23-40.

39. Fauconneau, B.; Choubert, G.; Blanc, D.; Breque, J.; Luquet, P. Influence of environmental temperature on flow rate of foodstuffs through the gastrointestinal tract of rainbow trout. Aquaculture, 34: 27-39; 1983.

40. Grove, D.J. Gastro-intestinal physiology: Rates of food processing in fish. In: Nilsson, S.; Holmgren, S., eds. Fish physiology: recent advances. London: Croom Helm; 1986: pp. 140-152.

41. Bergmeyer, H.U. $\alpha$-Amylase. In: Bergemeyer, H.U.; Grassl, M.; Walter, H.E., eds. Methods for enzymatic analysis. Vol. 2. Reinheim; Verlag Chimie: 1983: pp. 151153.

42. Worthington Enzyme Mutual. Enzymes, enzyme reagents and related biochemicals. New Jersey: Worthington Biochemical Corporation; 1972.

43. Pierre, K.J.; Tung, K.K. $\alpha$-Amylase. In: Bergemeyer, H.U., ed. Methods for Enzymatic Analysis. 3rd ed. Vol. 4. Reinheim; Verlag Chimie: 1984: pp. 146-161.

44. Boehringer Mannheim Biochemicals. Biochemica information. Keesey, J., Indianapolis: Boehringer Mannheim Biochemicals; 1987.

45. Natarajan, M.; Ross, B.; Ross, L.C. Susceptibility of carp and tilapia a-amylase to purified wheat amylase inhibitor. Aquaculture, 102: 265-274; 1992.

46. Alpers, D. H.; Solin, M. The characterization of rat intestinal amylase. Gastroenterology, 58: 833-842; 1970.

47. Gray, G.M. Carbohydrate digestion and absorption. N. Engl. J. Med., June: 1225$1230 ; 1975$.

48. Ferraris, R.P.; Ahearn, G. A. Sugar and amino acid transport in fish intestine. Comp. Biochem. Physiol., 77A: 397-413; 1984.

49. Vinardell, M.P. Mutual inhibition of sugars and amino acid intestinal absorption. Comp. Biochem. Physiol., 95A: 17-21; 1990.

50. Buddington, R.K. Does the natural diet influence the intestine's ability to regulate glucose adsorption? J. Comp. Physiol. B, 157: 677-688; 1987. 
TABLE 1. Number of fish, morphometric measurements and rearing conditions of the species studied in this work

\begin{tabular}{llllllll}
\hline Species & $\begin{array}{l}\text { Number } \\
\text { of fish }\end{array}$ & $\begin{array}{l}\text { Size } \\
\text { range } \\
(\mathrm{cm})\end{array}$ & $\begin{array}{c}\text { Weight } \\
\text { range }(\mathrm{g})\end{array}$ & $\begin{array}{l}\text { Tank } \\
\left(\mathrm{M}^{3}\right)\end{array}$ & Diet & $\begin{array}{l}\text { Organic } \\
\text { matter } \\
(\%)\end{array}$ & P:L:C:H* \\
& & & & & - \\
\hline Redfish & 18 & $22.0-$ & $320-810$ & Wild & Natural & - & - \\
& & 40.0 & & & & & \\
Seabream & 5 & $18.0-$ & $76-196$ & 2.7 & Semimoist & $83.93 \pm$ & $2: 2: 0.1$ \\
& & 22.5 & & & & 1.14 & \\
Turbot & 6 & $26.5-$ & $401-585$ & 20.0 & Semimoist & $83.93 \pm$ & $2: 2: 0.1$ \\
& & 32.0 & & & & 1.14 & \\
\hline
\end{tabular}

*Protein: lipid: carbohydrate ratio in the food.

TABLE 2. Some characteristics of the temperature dependence of amylase activity from redfish, seabream and turbot

\begin{tabular}{lllll}
\hline Segment & Species & Breakpoint at $\left({ }^{\circ} \mathrm{C}\right)$ & Ea $(\mathrm{kcal} / \mathrm{mol}) *$ & $\mathrm{Q}_{10}{ }^{\dagger}$ \\
\hline Stomach & Seabream & No & 11.71 & 2.09 \\
& Turbot & No & 7.77 & 3.05 \\
& Redfish & No & 16.41 & 4.25 \\
Intestine & Seabream & 19.9 & $2.40 / 19.13$ & $1.93 / 1.29$ \\
& Turbot & 23.6 & $7.22 / 16.57$ & $1.83 / 1.29$ \\
& Redfish & No & 7.92 & 1.87
\end{tabular}

*Ea values above breakpoint on the left and E, values below breakpoint on the right.

$\dagger Q_{10}$ values above breakpoint on the left and $Q_{10}$ values below breakpoint on the right.

TABLE 3. Effect of several compounds on the amylase activity from the gastrointestinal tract of redfish, seabream and turbot

\begin{tabular}{llllllll}
\hline & & \multicolumn{5}{l}{ Without calcium } & \multicolumn{5}{l}{ With calcium } \\
\cline { 4 - 8 } Inhibitor & {$[\mathrm{I}]$} & Seabream & Turbot & Redfish & Seabream & Turbot & Redfish \\
& $(\mathrm{mM})$ & & & & & & \\
\hline & & & & & & & \\
None & - & n.d. & 100.0 & $8.6 \pm 3.5$ & 100.0 & 100.0 & n.d. \\
$\mathrm{M}_{\mathrm{g} \mathrm{Cl}_{2}}$ & 10 & n.d. & $80.1 \pm$ & n.d. & n.d. & $86.1 \pm$ & $34.0 \pm$ \\
\hline
\end{tabular}




\begin{tabular}{|c|c|c|c|c|c|c|c|}
\hline & & & 1.1 & & & 3.0 & 2.9 \\
\hline $\mathrm{CuSO}_{4}$ & 10 & n.d. & $\begin{array}{l}3.0 \pm \\
1.2\end{array}$ & n.d. & $\begin{array}{l}29.3 \pm \\
5.3\end{array}$ & $\begin{array}{l}3.3 \pm \\
1.8\end{array}$ & n.d. \\
\hline EDTA & 5 & n.d. & $\begin{array}{l}99.8 \pm \\
3.0\end{array}$ & 100.0 & n.d. & $\begin{array}{l}96.2 \pm \\
1.7\end{array}$ & 100.0 \\
\hline Urea & 100 & n.d. & $\begin{array}{l}80.2 \pm \\
0.6\end{array}$ & $\begin{array}{l}46.5 \pm \\
3.8\end{array}$ & $\begin{array}{l}87.8 \pm \\
4.8\end{array}$ & $\begin{array}{l}67.9 \pm \\
1.7\end{array}$ & $6.8 \pm 0.7$ \\
\hline PCMB & 0.5 & n.d. & $\begin{array}{l}8.6 \pm \\
2.1\end{array}$ & $2.2 \pm 1.5$ & $\begin{array}{l}79.9 \pm \\
2.7\end{array}$ & $\begin{array}{l}36.1 \pm \\
2.8\end{array}$ & $6.6 \pm 3.8$ \\
\hline IAA & 5 & n.d. & n.d. & $\begin{array}{l}12.0 \pm \\
1.2\end{array}$ & n.d. & $\begin{array}{l}2.2 \pm \\
1.7\end{array}$ & n.d. \\
\hline None & - & n.d. & 100.0 & $\begin{array}{l}\text { Intestine } \\
13.4 \pm \\
0.0\end{array}$ & 100.0 & 100.0 & $\begin{array}{l}16.8 \pm \\
0.8\end{array}$ \\
\hline $\mathrm{M}_{\mathrm{g}} \mathrm{Cl}_{2}$ & 10 & n.d. & $\begin{array}{l}47.6 \pm \\
1.9\end{array}$ & $1.3 \pm 1.9$ & $6.3 \pm 2.0$ & $\begin{array}{l}76.7 \pm \\
1.5\end{array}$ & $4.2 \pm 1.7$ \\
\hline $\mathrm{CuSO}_{4}$ & 10 & n.d. & $\begin{array}{l}3.8 \pm \\
0.7\end{array}$ & n.d. & n.d. & $\begin{array}{l}0.5 \pm \\
0.3\end{array}$ & n.d. \\
\hline EDTA & 5 & n.d. & $\begin{array}{l}15.2 \pm \\
0.7\end{array}$ & 100.0 & n.d. & $\begin{array}{l}15.1 \pm \\
1.8\end{array}$ & 100.0 \\
\hline Urea & 100 & n.d. & $\begin{array}{l}3.9 \pm \\
1.6\end{array}$ & n.d. & $\begin{array}{l}75.5 \pm \\
3.0\end{array}$ & $\begin{array}{l}88.1 \pm \\
2.9\end{array}$ & $0.5 \pm 1.1$ \\
\hline PCMB & 0.5 & n.d. & $\begin{array}{l}6.4 \pm \\
0.9\end{array}$ & n.d. & $\begin{array}{l}75.0 \pm \\
6.9\end{array}$ & n.d. & $8.3 \pm 1.7$ \\
\hline IAA & 5 & n.d. & n.d. & n.d. & $6.1 \pm 5.2$ & $\begin{array}{l}75.8 \pm \\
2.9\end{array}$ & $6.9 \pm 2.5$ \\
\hline
\end{tabular}

The results are shown as percentages. (Note that this study was independently performed in the presence and absence of calcium ions.) n.d., not detectable. With calcium $=10 \mathrm{mM}$ of $\mathrm{Cl}_{2} \mathrm{C}_{\mathrm{a}}$ in the assay mixture. Note: $100 \%$ of activity does not necessarily mean the same specific activity.

FIG. 1. The effect of $\mathrm{pH}$ on the relative amylase activity from stomach (A) and intestine (B) of redfish $(\mathrm{O})$, seabream $(\square)$ and turbot $(\Delta)$. 
FIG. 2. The effect of temperature on the relative amylase activity from stomach (A) and intestine (B) of redfish $(\mathrm{O})$, seabream $(\square)$ and turbot $(\Delta)$.

FIG. 3. The effect of $\mathrm{NaCl}$ concentration on the relative amylase activity from stomach (A) and intestine (B) of redfish $(\mathrm{O})$, seabream $(\square)$ and turbot $(\Delta)$. 